\title{
Dobro wspólne jako wartość i zasada etyczno-społeczna. Perspektywa katolickiej nauki społecznej
}

\section{Wprowadzenie}

$\mathrm{O}_{\mathrm{w}}$ obro wspólne jest przedmiotem refleksji naukowej od starożytności aż po współczesność. Tak długi czas namysłu nie oznacza jednak jednolitego sposobu jego rozumienia, a wręcz przeciwnie, spory pluralizm ujęć. Różnorodność ta dotyczy nie tylko jego ujęć przez poszczególne dyscypliny naukowe, takie jak filozofia, prawo, ekonomia, socjologia czy politologia, lecz także wielości interpretacji dobra wspólnego w ramach poszczególnych dyscyplin. Przedmiotem analiz w artykule będą sposoby rozumienia samego dobra wspólnego oraz zasady dobra wspólnego na gruncie katolickiej nauki społecznej (KNS). Główny akcent zostanie położony na interpretację tych kategorii przez uczonych skupionych w Lubelskiej Szkole Katolickiej Nauki Społecznej (LSKNS)1, ze szczególnym uwzględnieniem wyników dociekań naukowych ks. Jana Szymczyka, który w swoich badaniach zajmował się m.in. metarefleksją nad koncepcjami dobra wspólnego formułowanymi w tym środowisku naukowym². Przy tym nie po-

* Ks. dr hab. Stanisław Fel, prof. KUL - Katedra Katolickiej Nauki Społecznej i Socjologii Moralności, Instytut Nauk Socjologicznych, Wydział Nauk Społecznych, Katolicki Uniwersytet Lubelski Jana Pawła II, e-mail: stanislaw.fel@kul.pl, ORCID: 0000-0003-3975-665X.

${ }^{1}$ F.J. Mazurek, Z. Skwierczyński, Lubelska Szkoła Katolickiej Nauki Społecznej, w: Encyklopedia katolicka, t. 11, red. S. Wilk i in., TN KUL, Lublin 2006, kol. 34-36.

${ }^{2}$ Wyniki badań z tego zakresu zawarł głównie w rozprawie doktorskiej: J. Szymczyk, Zasada dobra wspólnego w ujęciu przedstawicieli Szkoły Lubelskiej, Lublin 1996 [mps w Archiwum KUL] oraz w publikacjach: Wokót podstawowych zasad etyczno-społecznych, w: J. Szymczyk, Odkrywanie wartości. Z problematyki socjologiczno-aksjologicznej, Polihymnia, Lublin 2004, s. 11-97; Zasada dobra wspólnego a urządzanie życia społeczno-gospodarczego, w: Godność osoby ludzkiej w społeczeństwie i gospodarce, red. S. Fel, M. Wódka, Wydawnictwo KUL, Lublin 2014, s. 405-420. 
przestał jedynie na analizie koncepcji dobra wspólnego w twórczości głównych jego przedstawicieli zajmujących się tą problematyką, lecz podejmował próby syntezy pod kątem wypracowania ujęć charakterystycznych dla całej tej szkoły intelektualnej ${ }^{3}$.

Nierzadko w pracach poświęconych dobru wspólnemu nie rozróżnia się samej kategorii dobra wspólnego i zasady dobra wspólnego, w konsekwencji utożsamiając obydwie te kategorie. Tymczasem nie są one tożsame i wymagają wyraźnego rozróżnienia. W artykule przedstawiona zostanie zarówno sama kategoria dobra wspólnego jako wartości, jak również „stojąca na straży” jego realizacji zasada etyczno-społeczna.

Kluczowe znaczenie dla sposobu ujmowania powyższych zagadnień ma leżąca u ich podstaw koncepcja człowieka. Stąd też przedstawienie przedmiotowej kwestii wymaga przynajmniej jej zarysowania.

\section{Personalistyczna koncepcja człowieka}

Podstawowym punktem odniesienia dla rozumienia zarówno samego dobra wspólnego, jak i zasady dobra wspólnego, a także innych zasad etyczno-społecznych, jest koncepcja człowieka. W KNS wypracowano personalistyczną koncepcję człowieka jako osoby. Człowiek w tym ujęciu jest z jednej strony bytem skończonym, doskonałym i niepowtarzalnym, a z drugiej potencjalnym, dynamicznym, rozwojowym, wymagającym społecznego współdziałania, doskonalącym się najbardziej efektywnie przez własne działanie przy nieodzowności korzystania z zasobów dostarczanych przez inne osoby. Odpowiada to rozróżnieniu na to, co człowiekowi jest „dane” oraz na to, co jest mu „zadane”. Dana jest mu cielesno-duchowa natura, a przede wszystkim wolność i rozumność, które przesądzają o posiadaniu wrodzonej i niezbywalnej osobowej godności. Zapisana w naturze człowieka rozwojowość, dążność do doskonalenia się jest mu „zadana”. Realizacji tego zadania człowiek może podołać jedynie dzięki pomocy innych i społecznemu współdziałaniu. Fakt ten stanowi przesłankę do uznania jego społecznej natury ${ }^{4}$. Społeczny aspekt koncepcji osoby ludzkiej

${ }^{3}$ Zasadniczym przedmiotem badań był dorobek Czesława Strzeszewskiego, ks. Józefa Majki, ks. Joachima Kondzieli, ks. Jana Kruciny oraz ks. Władysława Piwowarskiego. W mniejszym stopniu analizował myśl ks. Franciszka J. Mazurka. Chociaż J. Szymczyk nie wskazywał expressis verbis inspiracji intelektualnych eksplorowanych koncepcji, to przywoływana w tym kontekście literatura pośrednio wskazuje, przynajmniej częściowo, ścieżki do nich prowadzące.

${ }^{4}$ Takie odczytanie społecznej natury człowieka stanowi przedmiot dyskursu filozofów społecznych zmierzającego do znalezienia odpowiedzi na pytanie, czy „skazanie” człowieka na pomoc innych jest przejawem swoistego mankamentu, ograniczoności jego natury, czy też jej doskonałości. Ponieważ przedstawienie tej kwestii, nawet w zarysie, nie jest możliwe w krótkim artykule, niech tutaj wystarczy stwierdzenie, że na gruncie KNS rozpatrywanie problemu braku samowystarczalności 
wskazuje na konieczność istnienia dobra wspólnego, uznania go za wartość oraz sformułowania etyczno-społecznej zasady dobra wspólnego stojącej na straży jego realizacji. Z kolei inne aspekty personalistycznej wizji człowieka stanowią przesłankę do formułowania kolejnych podstawowych zasad etyczno-społecznych, a mianowicie: pomocniczości i solidarności, a przede wszystkim odczytywania z niej praw człowieka, mających swą podstawę w godności osoby ludzkiej. Konieczne wydaje się przypomnienie, że takie aspektowe analizowanie koncepcji człowieka jest zabiegiem sztucznym, stosowanym dla lepszego jej zrozumienia, a faktycznie jest on wielowymiarową, ale zawsze integralną, niepodzielną całością.

\section{Dobro wspólne jako wartość}

Istnieje wiele sposobów definiowania wartości. Są one różnie rozumiane w ramach takich dyscyplin, jak socjologia, ekonomia czy filozofia. Pojęciowe zagmatwanie w kwestii określenia wartości było w socjologii przyczyną nawet tak absurdalnych postulatów, jak rezygnacja z zajmowania się tą problematyką ${ }^{5}$. J. Szymczykowi bliskie wydaje się być określenie socjologiczne wartości jako tego wszystkiego, „co wiąże się z pozytywnymi emocjami, co skupia w sobie dążenia i pragnienia człowieka, co uważa się za istotne w życiu, godne pożądania, na zdobyciu czego jednostce najbardziej zależy oraz czego się na co dzień poszukuje jako rzeczy cennej”" Od takiego ujęcia wartości nie odbiega jej określenie w aksjologii filozoficznej nazywającej wartością wszystko to, co cenne i godne pożądania, i co w konsekwencji stanowi cel ludzkich dążeń. Na gruncie filozofii społecznej rozróżnia się wartości obiektywne i subiektywne. Obiektywne oznaczają wartość jako cechę przysługującą danemu przedmiotowi niezależnie od jego subiektywnego wartościowania. Natomiast w przypadku subiektywnych wartość jest nadawana przez oceniający podmiot, co faktycznie odnosi się bardziej do postaw wobec danej rzeczy czy zjawiska oceniających

człowieka nie ogranicza się do niezdolności do samodzielnego zaspokojenia wszystkich potrzeb i do samej dążności do życia społecznego, lecz kieruje uwagę na właściwy tylko osobom ludzkim przymiot harmonijnego współżycia, wspólnego osiągania celów i tworzenia ładu społecznego opartego na zasadach moralnych. Zdaniem O. von Nell-Breuninga, najwybitniejszego niemieckiego przedstawiciela KNS, „istotą społeczną czynią człowieka nie tyle jego braki czy jego niesamowystarczalność, lecz przede wszystkim jego ukierunkowanie na wartości wyższe, możliwe do urzeczywistnienia tylko w relacjach międzyludzkich, zatem jego ewidentna doskonałość; to ona przesądza o jego społecznej naturze i podnosi go do statusu istoty społecznej". O. von Nell-Breuning, Gerechtigkeit und Freiheit. Grundzüge katholischer Soziallehre, Europaverlag, Wien-Zürich-München 1980, s. 21; J. Szymczyk, Zasada dobra wspólnego..., s. 32-53.

${ }^{5}$ J. Szymczyk, Odkrywanie wartości..., s. 121.

6 Tamże, s. 123. 
podmiotów, niż do samego przedmiotu oceny. Na użytek rozważań z perspektywy KNS, w swojej istocie ukierunkowanej na dobro i rozwój osoby ludzkiej, adekwatne wydaje się określenie wartości jako tego wszystkiego, co służy człowiekowi ${ }^{7}$. Takie rozumienie wartości jednoznacznie każe postrzegać dobro wspólne jako wartość.

W KNS ukształtowały się dwa podstawowe sposoby rozumienia dobra wspólnego. Jeden $\mathrm{z}$ nich, wypracowany głównie na gruncie tomizmu przez myślicieli dominikańskich, nazywany jest koncepcją immanentną (również esencjalną lub ontyczną). Jej najbardziej znaczącym nowożytnym przedstawicielem jest Arthur F. Utz. Druga z nich, rozwinięta głównie przez uczonych jezuickich, nazywana jest koncepcją instrumentalną. Najbardziej znanym jej przedstawicielem jest Oswald von Nell-Breuning. A.F. Utz, traktując dobro wspólne immanentnie, uznaje je za miarę doskonałości ustaloną dla człowieka przez naturę, akcentuje przy tym samoistność dobra wspólnego jako ideału (w pewnym sensie niezależnego od aktualnych uwarunkowań społecznych), do którego zmierzają uspołecznieni ludzie. Dobro jednostkowe poszczególnej osoby ma się tak do dobra wspólnego, jak część do całości ${ }^{8}$. Tylko w niektórych aspektach (np. duchowym) uznaje nadrzędność dobra indywidualnego nad dobrem wspólnym. Społeczna natura osoby ludzkiej jest tu interpretowana w sposób przyjmujący możliwość osiągnięcia indywidualnej osobowej doskonałości jedynie w ramach systemu społecznego, a punktem wyjścia do tego jest całościowy ład społeczny. Jak wykazuje J. Szymczyk, w LSKNS najbardziej wyrazistym reprezentantem takiego ujęcia jest ks. Jan Krucina, który jednak docenia także rolę instrumentalnego dobra wspólnego ${ }^{9}$. Z kolei O. von Nell-Breuning uważa, że dobro wspólne to zespół środków, uwarunkowań i instytucji, stwarzających dla ludzi optymalne możliwości ich rozwoju. Waloru społeczeństwa upatruje on w wartościach, które nie mogą zaistnieć w samej jednostce ludzkiej, lecz tylko w relacjach międzyludzkich w ramach aktualnych społecznych powiązań. Według niego społeczeństwo jest „trwałym i skutecznym związkiem ludzi w dążeniu do urzeczywistnienia wspólnego celu lub wartości”11. Bonum commune jako cel i wartość społecznego zjednoczenia jest wspólnym dobrem akceptowanym i pożądanym jako wartość sama w sobie. Jednak swoją etyczną wartość czerpie ono z faktu urzeczywistniania się w człowieku, tzn. z wkładu dobra wspólnego w rozwój i udoskonalenie się osoby ludzkiej. Zatem chociaż

${ }^{7}$ K. Popielski, Wprowadzenie. Wartości i ich społeczno-kulturowe znaczenie, w: Wartości dla życia, red. K. Popielski, Wydawnictwo KUL, Lublin 2008, s. 5-6, 68.

8 A.F. Utz, Ethik des Gemeinwohls. Gesammelte Aufsätze 1983-1997, Ferdinand Schöningh, Paderborn 1998, s. 166-170.

9 J. Szymczyk, Zasada dobra wspólnego..., s. 185-187.

${ }^{10}$ O. von Nell-Breuning, Gemeingut, Gemeinwohl, w: Wörterbuch der Politik, t. 1. Zur christlichen Gesellschaftslehre, red. O. von Nell-Breuning, H. Sacher, Herder, Freiburg im Breisgau 1954, s. 53. 
w ujęciu tym punktem wyjścia jest osoba ludzka, a dobro wspólne ma charakter instrumentalno-instytucjonalny, to jego specyfikę stanowią wartości i cele, które ludzie mogą osiągać tylko przez społeczne zjednoczenie i w których mogą mieć udział jedynie jako członkowie społeczeństwa. W LSKNS takie ujęcie rozwijał głównie ks. Władysław Piwowarski ${ }^{11}$. Należy zaznaczyć, że każdy z pięciu wspomnianych lubelskich badaczy dobra wspólnego odnajdywał w jakimś stopniu cenne elementy w obydwu koncepcjach, rozwijając je w kierunku ujęcia łączącego zalety obydwu podejść ${ }^{12}$.

Te podstawowe sposoby rozumienia dobra wspólnego są dopełniane przez ujęcia wyłaniające się z uwarunkowań jego poznania oraz związanych z tym modeli jego uzasadniania. Koncepcje aprioryczno-normatywne wychodzą $\mathrm{z}$ „założenia istnienia uprzednio zdefiniowanego ogólnego dobra wspólnego, (...) które nie wymaga empirycznie potwierdzanej akceptacji społeczeństwa lub też członków wspólnoty"13. Brak potrzeby akceptacji nie oznacza jednak dowolności w podporządkowaniu się przez nich dobru powszechnemu. Z kolei koncepcje aposterioryczne ujmują dobro wspólne w perspektywie historyczno-dynamicznej, ukierunkowują się przy tym na dobro jednostki oraz na podstawie empirycznych ustaleń i uzasadnień projektują organizacyjny kształt dobra wszystkich jednostek. Niezależnie od sposobu ujmowania dobra wspólnego, czy to jako normatywnej idei, czy też jako empirycznie ustalanego elementu struktury społecznej, chodzi w nich zawsze o właściwą relację między jednostką i wspólnotą oraz zabezpieczający taką relację kształt ładu społecznego. Implikuje to istnienie kompetentnej instancji odpowiedzialnej za jego realizację.

W świetle rozumianej interdyscyplinarnie KNS należy zatem dowartościować zarówno charakterystyczne dla koncepcji ontycznej filozoficzne uzasadnienie dobra wspólnego, jak i bliższe koncepcji instrumentalnej konkretne rozwiązania polityczno-prawne i społeczno-gospodarcze służące jego realnemu urzeczywistnieniu. Z koncepcją ontyczną koresponduje ukierunkowanie na pewien idealny cel, zaś z koncepcją instrumentalno-instytucjonalną ukierunkowanie na struktury i mechanizmy służące osiąganiu celu, jakim jest dobro wspólne, a ostatecznie doskonalenie się osoby ludzkiej ${ }^{14}$. Mimo pluralizmu ujęć w ramach LSKNS, w wielości stanowisk przedstawicieli tego środowiska

11 W. Piwowarski, $A B C$..., s. 63

12 J. Kondziela, Filozofia społeczna, Zagadnienia wybrane, Wydawnictwo KUL, Lublin 1972; J. Majka, Filozofia społeczna, Ośrodek Dokumentacji i Studiów Społecznych, Wrocław 1982; C. Strzeszewski, Hierarchia dóbr wspólnych a naturalna hierarchia społeczności, „Roczniki Filozoficzne” 1966, t. 14, z. 2, s. 5-11; C. Strzeszewski, Katolicka nauka społeczna, Redakcja Wydawnictw KUL, Lublin 1994, s. 520-524.

13 R.-O. Schulze, Gemeinwohl, w: Lexikon der Politik, t. 1. Politische Theorien, red. D. Nohlen, C.H. Beck. München 1995, s. 137.

14 J. Szymczyk, Wokót podstawowych zasad..., s. 25. 
zwykle istnieje jakiś wspólny rdzeń umożliwiający odnalezienie wspólnego mianownika. Takich syntezujących ujęć m.in. przy analizach problematyki dobra wspólnego poszukiwał J. Szymczyk. Uznaje on, że dobro wspólne w rozumieniu LSKNS należy ujmować syntetyzująco jako koncepcję zarazem ontyczną i instrumentalną ${ }^{15}$. Przy tym, upatrując we wspomnianych ujęciach dwóch wymiarów tej samej rzeczywistości, konsekwentnie pisze on o immanentnym (wewnętrznym) i instrumentalnym (zewnętrznym) aspekcie dobra wspólnego ${ }^{16}$. W tym kontekście jeszcze raz jawi się pytanie o drogę dochodzenia do poznania dobra wspólnego i ustalenia jego przymiotów. Czy jest to droga dedukcyjna, polegająca na jego spekulatywnym wywodzeniu z koncepcji człowieka - osoby ludzkiej, czy też jest to droga indukcyjna, poszukująca przesłanek do uzasadnienia istnienia i cech dobra wspólnego w realiach funkcjonowania człowieka w praktyce rzeczywistości społeczno-gospodarczej? Oznacza to konieczność sięgania odpowiednio albo po metody właściwe filozofii, albo naukom społecznym ${ }^{17}$. Wspomniany interdyscyplinarny charakter uprawiana KNS w lubelskiej szkole pozwala połączyć obydwie te drogi, unikając z jednej strony oderwanego od życia idealizmu, a z drugiej wyprowadzania zasad moralności z aktualnych zachowań społecznych. Ostatecznie chodzi o stworzenie takich struktur społecznych, które umożliwią osobie ludzkiej dążenie do wieloaspektowo rozumianego udoskonalenia. „Dobro wspólne jest synonimem tego wszystkiego, co w danej społeczności powinno być urzeczywistnione w postaci warunków wstępnych, uwarunkowań lub rozwiązań instytucjonalnych, sprzyjających temu, aby jednostki przez własną aktywność mogły osiągnąć swoje dobro indywidualne i wspólne (udział w dobru wspólnym)"18. Zatem jest to dynamiczne ujęcie dobra wspólnego, wymagające korekt istniejących rozwiązań strukturalnych i instytucjonalnych, tak aby zawsze optymalnie służyły integralnemu rozwojowi osoby.

Rekonstruując koncepcję dobra wspólnego w KNS, przydatne wydaje się przywołanie historycznego kontekstu ideowego i praktycznego, w jakim się ona kształtowała. W ponad stutrzydziestoletniej tradycji oficjalnego nauczania społecznego Kościoła prowadzono polemiczny dyskurs z przedstawicielami specyficznych sposobów rozumienia „dobra wspólnego", z jednej strony w ujęciu indywidualistyczno-liberalnym, a z drugiej w interpretacji kolektywistycznej. W tym pierwszym rozumieniu „dobro wspólne” sprowadza się do zwykłej sumy jednostkowych interesów członków danej społeczności. Ogranicza się

15 Tenże, Zasada dobra wspólnego..., s. 191, 297.

16 Tenże, Wokót podstawowych zasad..., s. 31.

17 Droga indukcyjna oznacza ryzyko popadnięcia w socjologizm. Zob. M. Gierycz, Mała pochwała katolicyzmu. Kościót i polityka w późnej nowoczesności, Wydawnictwo Teologia Polityczna, Warszawa 2021, s. 356-359.

${ }^{18}$ O. von Nell-Breuning, Gemeingut, Gemeinwohl, s. 55. 
ono głównie do wymiaru materialnego i nie stanowi oddzielnej, samoistnej kategorii zawierającej komponent normatywno-moralny - wartości samej w sobie. Jedynymi realnymi podmiotami życia społecznego są jednostki ludzkie, a w konsekwencji istnieje tylko indywidualne dobro jednostkowe. Stąd też bardziej adekwatnym określeniem tak rozumianego „dobra wspólnego” wydaje się być interes ogółu czy dobro powszechne. W drugim ujęciu jawi się ono jako kategoria nadrzędna wobec jednostek, oznaczająca dobro społeczności ujmowanych jako kategoria pierwotna, jak klasa robotnicza (w rozumieniu marksowskim), naród (w rozumieniu nazistowskim) czy państwo (w ujęciu faszystowskim). W tym odrzucanym przez KNS podejściu człowiek czerpie rację swojego istnienia z bycia częścią, emanacją lub tė̇ „użytecznym trybikiem” tak rozumianej społeczności. W ujęciu autorów LSKNS przesuwających akcenty raz na osobę, innym razem na dobro wspólne, nigdy nie traci ono osobowego charakteru, służąc ostatecznie egzystencji i rozwojowi osoby ludzkiej. Współcześnie pojawiają się nurty, także w chrześcijańskiej nauce społecznej, postulujące włączenie do kategorii dobra wspólnego elementów przyrody ożywionej i nieożywionej ${ }^{19}$. W ich ramach podejmowane są próby poszerzenia o nie zakresu dobra wspólnego, a w konsekwencji zasady dobra wspólnego. Dążenia takie nasiliły się w związku z bezpośrednim włączeniem do nauczania społecznego Kościoła przez papieża Franciszka kwestii środowiska naturalnego ${ }^{20}$, chociaż już wcześniej pojawiały się postulaty rozbudowania katalogu podstawowych zasad etyczno-społecznych o zasadę zrównoważonego rozwoju obejmującą również środowisko naturalne. Markus Vogt w sformułowanej przez siebie propozycji zasady zrównoważonego i trwałego rozwoju (Prinzip Nachhaltigkeit) dostrzega alternatywę dla zasady dobra wspólnego ${ }^{21}$. Ujęcie takie nie znalazło dotychczas akceptacji w oficjalnych wypowiedziach nauczania społecznego Kościoła ani też wśród większej grupy autorów zajmujących się $\mathrm{KNS}^{22}$. Jeszcze dalej idą propozycje formułowane z perspektywy etyki ekocentrycznej, w ramach której

19 H. Wulsdorf, Nachhaltigkeit. Ein christlicher Grundauftrag in einer globalisierten Welt, Friedrich Pustet, Regensburg, 2005.

20 Franciszek, Encyklika Laudato si', 2015.

21 M. Vogt, Globales Gemeinwohl und Nachhaltigkeit, w: Globales Gemeinwohl. Sozialwissenschaftliche und sozialethische Analysen, red. M. Heimbach-Steins i in., Brill - Ferdinand Schöningh, Paderborn 2020, s. 185-207. Zob. S. Fel, Ł. Marczak, Powstanie i status zasady zrównoważonego rozwoju, „Roczniki Nauk Społecznych” 2016, nr 2, s. 185-205.

22 Nauczanie społeczne pozostaje przy nieco zmodyfikowanym pod względem kładzenia akcentów podejściu antropocentrycznym, używając kategorii rozwój integralny. Chociaż uwzględnia ono w istotny sposób kontekst przyrodniczy funkcjonowania człowieka, pozostaje nadal w sferze relacji międzyludzkich. Także w debacie naukowej prowadzonej na gruncie KNS nie przedłożono dotychczas argumentacji za odejściem od ujęcia antropocentrycznego, która znalazłaby szeroką akceptację. Ł. Marczak, Zasada zrównoważonego rozwoju. Perspektywa społeczno-etyczna, Wydawnictwo Naukowe Uniwersytetu Papieskiego Jana Pawła II w Krakowie, Kraków 2021, s. 156. 
postuluje się uznawanie na równi z człowiekiem podmiotowości elementów świata przyrody, zwłaszcza istot zdolnych do odczuwania cierpienia ${ }^{23}$. Jest poniekąd oczywiste, że jako dalej idące w stosunku do wyżej wspomnianych, także i one nie znajdują szerszej akceptacji na gruncie KNS ${ }^{24}$.

\section{Zasada etyczno-społeczna dobra wspólnego}

W KNS zasady etyczno-społeczne stoją przede wszystkim na straży człowieka jako osoby, wyposażonej we wrodzoną i niezbywalną godność, uznawanej za najważniejszą wartość w świecie przyrodzonym - wartość wartości. „Jako istota rozumna i wolna, podmiot praw i obowiązków, jest pierwszą zasadą oraz - można powiedzieć - sercem i duszą nauki społecznej Kościoła”25, a jego godność jest fundamentem zasad współtworzących korpus $\mathrm{KNS}^{26}$. Zatem również zasada dobra wspólnego zastosowana w praktyce życia społeczno-gospodarczego powinna wspierać optymalny rozwój osoby ludzkiej. Przy tym samo pojęcie zasady etyczno-społecznej jest różnorako rozumiane przez autorów zajmujących się KNS, a nawet w dokumentach nauczania społecznego ${ }^{27}$. Brak precyzyjnego ich zdefiniowania skutkuje tworzeniem, niekiedy dość obszernych ich katalogów ${ }^{28}$. Często za zasady uznaje się wręcz prawie wszystkie pozytywne elementy życia społeczno-gospodarczego, przede wszystkim wartości, a nawet ustroje społeczno-polityczne, jak demokracja.

U podstaw przyjętego tutaj katalogu zasad społecznych LSKNS leży zakorzeniona $\mathrm{w}$ arystotelesowsko-tomistycznej tradycji filozofia personalistyczna, w której przyjmuje się, że człowiek jest $\mathrm{z}$ natury istotą społeczną ukierunkowaną na dążenie do swoich celów przez wspólne działanie. W tym ujęciu, w wymiarze przyrodzonym najwyższą wartością jest osoba ludzka, zaś zasady społeczno-etyczne służą ochronie jej podmiotowości i możliwości rozwoju.

${ }^{23}$ K. Remele, Wessen Wohl? Welche Gemeinschaft? Für eine postanthropozentrische Ausweitung des Gemeinwohlverständnisses, w: Globales Gemeinwohl..., s. 163-174.

${ }^{24}$ M. Möhring-Hesse, Wem ist wohl beim Gemeinwohl? Pragmatische Erkundungen eines politischen Konzepts, w: Globales Gemeinwohl..., s. 139-162.

${ }^{25}$ Sobór Watykański II, Konstytucja duszpasterska o Kościele w świecie współczesnym Gaudium et spes, 1965, nr 17.

${ }^{26}$ Kongregacja ds. Wychowania Katolickiego, Wskazania dotyczace studiów i nauczania doktryny społecznej Kościoła w ramach formacji kapłańskiej, „L'Osservatore Romano” 1989, nr 10, s. 11, nr 31.

${ }^{27}$ J. Szymczyk, Wokół podstawowych zasad..., s. 12.

${ }^{28}$ Również poszczególni przedstawiciele LSKNS różnie systematyzowali podstawowe zasady społeczne. J. Szymczyk przyczyn takiego stanu rzeczy upatruje w fakcie zróżnicowania stopnia ich zainteresowania tą problematyką i trwaniem procesu ich systematyzacji. W. Piwowarski, ABC katolickiej nauki społecznej, Wydawnictwo Diecezjalne, Pelplin 1993, s. 62; J. Kupny, Podstawowe zasady życia społecznego, w: Katolicka nauka społeczna. Podstawowe zagadnienia z życia społecznego i politycznego, red. S. Fel, J. Kupny, Księgarnia św. Jacka, Katowice 2007, s. 76-87. 
U fundamentów bazującej na tym systemie filozoficznym wizji życia społecznego leży przekonanie, że mimo priorytetowej wartości osoby ludzkiej i jej priorytetowego uprawnienia do samodzielnej realizacji swoich celów, nie jest ona w stanie dokonać tego indywidualnie. W tym kontekście formułuje się definicję zasady etyczno-społecznej. Odróżnia się ją przy tym od zasady moralnej, również odkrywanej przez rozum ludzki i postrzeganej jako zobowiązanie do jej realizacji, ale w wymiarze indywidualnym. Natomiast w przypadku zasady społecznej chodzi o poznanie i realizację wartości, których jednostka nie jest $\mathrm{w}$ stanie osiągnąć bez współpracy z innymi osobami ${ }^{29}$. Określa się ją zatem jako „nakaz rozumu praktycznego, który ustanawia zbiorową wartość i nakłada ją ludziom do wspólnej realizacji w społeczności" ${ }^{30}$. Ta definicja zasady etyczno-społecznej została upowszechniona w KNS przez ks. W. Piwowarskiego w nieco uproszczonej postaci jako "nakaz rozumu praktycznego do tworzenia wartości wspólnych jako środków służących do realizacji celów osobowych"”1. Celem życia społecznego jest dobro wspólne, które „polega na tworzeniu maksymalnych szans rozwoju jednostkom ludzkim, przynależnym do różnych społeczności" ${ }^{2}$. Na straży możliwości realizacji tych wartości i celów stoi zasada dobra wspólnego. W odniesieniu do osoby ludzkiej jako centralnej wartości należy zaznaczyć, że dobro wspólne jest wartością o charakterze instrumentalnym. Położenie akcentu na społeczne realizowanie powyższych celów nie oznacza bowiem rezygnacji z podmiotowej pozycji każdej osoby ludzkiej. Podmiotowości tej strzeże zasada pomocniczości (subsydiarności), która skorelowana $\mathrm{z}$ dobrem wspólnym ma zapewniać zobowiązanym do tworzenia wartości wspólnych możliwość realizacji uprawnienia do korzystania $\mathrm{z}$ nich. Zasada pomocniczości, określająca wzajemne stosunki społeczne pomiędzy społecznością i osobą oraz pomiędzy społecznościami większymi i mniejszymi, pomaga zachować autonomię jednostkom i mniejszym grupom społecznym m.in. poprzez niesienie im pomocy jedynie w takim zakresie, w jakim potrzebują jej do odzyskania zdolności do samodzielnego funkcjonowania ${ }^{33}$. Zasada subsydiarności zabezpiecza więc podmiotowość człowieka i sprzeciwia się kształtowaniu warunków życia społeczno-gospodarczego, które sprowadzałyby jednostkę społeczną do biernego przedmiotu ${ }^{34}$. Cele

29 J. Szymczyk, Wokół podstawowych zasad..., s. 13.

30 J. Krucina, Dobro wspólne. Teoria i jej zastosowanie, TUM Wydawnictwo Wrocławskiej Księgarni Archidiecezjalnej, Wrocław 1972, s. 110.

31 W. Piwowarski, $A B C \ldots$, s. 65.

32 Tamże, s. 77.

33 C. Strzeszewski, Katolicka nauka społeczna, s. $518 \mathrm{nn}$.

34 J. Chwaszcz, I. Niewiadomska, S. Fel, M. Wiechetek, A. Palacz-Chrisidis, Innowacyjne narzędzia do diagnozy potencjału readaptacyjnego osób zagrożonych wykluczeniem społecznym i zawodowym, Wydawnictwo Naukowe PWN, Warszawa 2015, s. 102-105. 
osobowe realizowane na drodze kreowania wartości wspólnych osiągane są w sposób optymalny przez aktywne i podmiotowe działanie aktorów społecznych. Zasada pomocniczości jest zatem także podstawową, uniwersalną zasadą życia społecznego, niezbędną do osiągania swoich celów przez osoby, których rozwój wpisany jest w mechanizm brania ze społeczności, jak i wnoszenia do niego swojego wkładu. Kluczowy dla rozumienia podstawowych zasad etyczno-społecznych w LSKNS jest właściwy balans przy ich stosowaniu. Przeakcentowanie znaczenia zasady dobra wspólnego może w praktyce prowadzić do krytykowanego w KNS modelu państwa (nad)opiekuńczego, osłabiającego troskę o swoje sprawy poszczególnych osób i społeczności mniejszych przy równoczesnym powstawaniu syndromu pasażera na gapę i wzmacnianiu postaw roszczeniowych. $Z$ kolei indywidualistyczno-liberalna nadinterpretacja zasady pomocniczości grozi zmierzaniem ku modelowi państwa minimum $\mathrm{z}$ atomizacją społeczeństwa oraz praktycznym zanegowaniem personalistycznie rozumianego dobra wspólnego ${ }^{35}$.

Osoba ludzka dążąc do realizacji zakorzenionych w potencjalnej naturze różnorakich celów, tworzy (włącza się w) różnego rodzaju społeczności. Każda z takich społeczności posiada swoje specyficzne dobro wspólne. Wszystkie te społeczności, mniejsze i większe, tworzą pewną społeczną całość, odzwierciedlającą pluralizm społeczny, tzn. potrzeby i prawa człowieka do życia w wielu społecznościach. W tym kontekście mówi się o istnieniu hierarchii wspólnot i społeczności, celów oraz dóbr wspólnych ${ }^{36}$. Pewną trudność w ustaleniu tej hierarchii stanowi kwestia ilościowego i jakościowego charakteru poszczególnych społeczności, gdyż o ich znaczeniu dla doskonalenia się osoby ludzkiej nie przesądza jedynie ich wielkość, ale też jakość więzi łączących z nimi jej członków ${ }^{37}$. Kwestia ta staje się szczególnie doniosła przy relacjach zasady dobra wspólnego i zasady pomocniczości. Chodzi przy tym głównie o kolejność udzielania pomocy społecznościom mniejszym przez większe bez naruszania autonomii i podmiotowości poszczególnych osób i społeczności mniejszych.

Zasady etyczno-społeczne mają zastosowanie przy konstruowaniu i funkcjonowaniu szeroko rozumianego życia społecznego, obejmującego takie jego subsystemy, jak społeczeństwo, gospodarka, polityka i kultura. Chodzi o zachowanie właściwych proporcji w przestrzeni między osobą ludzką a dobrem wspólnym, między społecznościami mniejszym a większymi. W. Piwowarski za papieżem Piusem XII, a poniekąd też za Gustawem Gundlachem wskazuje na dwa podstawowe mechanizmy wyrażające istotę życia społecznego: „dawanie”

35 J. Szymczyk, Jakie państwo: opiekuńcze czy pomocnicze?, „Chrześcijanin w Świecie” 1993, R. 23, nr 2 (193), s. 209-231.

36 J. Szymczyk, Zasada dobra wspólnego..., s. 239-261.

37 C. Strzeszewski, Hierarchia dóbr wspólnych..., s. 8-10. 
i „branie”. Dawanie oznacza wkład jednostek w dobro wspólne poszczególnych społeczności. Wkład ten kreuje wartości wspólne warunkujące rozwój osobowości ludzkiej. Z kolei „branie” oznacza korzystanie z tak wytworzonego dobra wspólnego. Zaznacza przy tym, że „dokonuje się to w społecznej kooperacji i polega na międzyosobowym komunikowaniu wartości wspólnych, tak w płaszczyźnie wkładu w życie społeczne, jak i w płaszczyźnie korzystania $z$ tego życia. Obydwie te tendencje i płaszczyzny wzajemnie się uzupełniają. Stanowią dwie strony tej samej rzeczywistości społecznej"38. Zasada dobra wspólnego bazuje na tendencji określanej jako „dawanie”. Chodzi o wkład jednostek w dobro wspólne i społeczności mniejszych w dobro wspólne społeczności większych, aż do społeczności ogólnoludzkiej włącznie. Na podstawie tej zasady określa się obowiązki „od dołu” oraz uprawnienia „od góry”. Zatem stroną uprawnioną jest zazwyczaj państwo lub społeczności szersze, a stroną zobowiązaną osoba i społeczności mniejsze. Z zasady dobra wspólnego wywodzi się zobowiązanie do wkładu w życie społeczne wnoszonego przez wszystkie podmioty tego życia. Wkład ten warunkuje rozwój oraz jakościowe i ilościowe bogactwo życia społecznego, a w konsekwencji pełny rozwój całego i każdego człowieka. Obok zasady dobra wspólnego i zasady pomocniczości triadę podstawowych zasad tworzy zasada solidarności ${ }^{39}$. Opiera się ona na obydwu wspomnianych tendencjach. Wyrażają ją takie hasła, jak: „Wszyscy znajdujemy się w jednej łodzi”, „Wszyscy za jednego, jeden za wszystkich”. Przy czym treść wyrażająca wzajemne powiązania („Wszyscy znajdujemy się w jednej łodzi") stanowi podstawę wzajemnej odpowiedzialność za siebie („Wszyscy za jednego, jeden za wszystkich”). Każdy ma być odpowiedzialny za całość, której jest częścią; całość ma odpowiadać za każdego ze swoich członków. Aspektowe podobieństwo do zasady dobra wspólnego sprawia, że niektórzy autorzy je utożsamiają.

\section{Dobro wspólne a sprawiedliwość}

Takie ujęcie dobra wspólnego i podstawowych zasad etyczno-społecznych wskazuje na ich silne powiązanie ze sprawiedliwością. Chodzi przecież o ciężary nakładane na wnoszących wkład w dobro wspólne oraz o korzyści czerpane z wykreowanych na tej drodze zasobów, a przed wszystkim o ich właściwe proporcje. Wymaga to uwzględnienia wielu korelujących ze sobą elementów, takich jak potrzeby i możliwości, oraz miar, jak równość i proporcjonalność. Zakorzeniona w myśli arystotelesowsko-tomistycznej klasyczna koncepcja

\footnotetext{
38 W. Piwowarski, $A B C$..., s. 63-64.

39 J. Szymczyk, Zasada dobra wspólnego..., s. 106.
} 
sprawiedliwości wyróżnia trzy jej rodzaje: zamienną (iustitia commutativa), rozdzielczą (iustitia distributiva) i prawną (iustitia legalis). Ta pierwsza oparta na kryterium równości reguluje w różnych aspektach relacje między równymi podmiotami. Druga opiera się głównie na kryterium proporcjonalności oraz potrzeb i priorytetowo wiąże się z aplikacją zasady pomocniczości. $\mathrm{Z}$ zasadą dobra wspólnego najmocniej łączy się sprawiedliwość prawna, regulująca głównie kwestię zobowiązań na rzecz dobra wspólnego. Opiera się zasadniczo na kryterium proporcjonalności i możliwościach zobowiązanych podmiotów. Wzajemnie skorelowana, w miarę harmonijna realizacja wszystkich jej rodzajów, sprawiedliwość pozwala mówić o rzeczywistym zaistnieniu sprawiedliwości społecznej (iustitia socialis). O ile na gruncie etyczno-społecznym postulaty dotyczące sprawiedliwości znajdują dość spójne filozoficzne uzasadnienie, o tyle jej praktyczna realizacja napotyka na szereg trudności, budzi emocjonujące debaty i jest przedmiotem empirycznych badań społecznych ${ }^{40}$. Przede wszystkim jednak złożony problem sprawiedliwości kieruje uwagę ku instancji odpowiedzialnej za praktyczną realizację dobra wspólnego.

\section{Państwo jako podmiot odpowiedzialny za realizację dobra wspólnego}

Analiza życia społecznego pokazuje, że chociaż członkowie społeczeństwa teoretycznie akceptują wspólne wartości i cele, to w rzeczywistości nierzadko starają się unikać związanych z tym zobowiązań. Zjawisko to nasila się wraz $\mathrm{z}$ wielkością danej społeczności i jej pluralizmem światopoglądowym ${ }^{41}$. Pojawia się zatem konieczność istnienia jakiejś władzy, która troszczyłaby się o respektowanie i realizację dobra wspólnego. Chociaż dotyczy to zasadniczo każdej społeczności, to zazwyczaj kategorię dobra wspólnego w aspekcie władzy odnosimy do dobra społeczności, której formalne ramy wyznacza państwo ${ }^{42}$. Wprawdzie coraz więcej elementów umożliwiających realizację dążenia osoby ludzkiej do doskonałości znajduje się poza granicami i zasięgiem kompetencyjnym poszczególnych państw oraz coraz częściej wymaga kooperacji międzynarodowej i globalnej, to jednak nadal nie ma globalnej instytucji mogącej w tym względzie efektywnie pełnić funkcję w sposób porównywalny do jej

40 S. Fel, Znaczenie społecznych badań empirycznych dla etyki. Na przykładzie sprawiedliwości społecznej, w: Wolność. Wieczne wyzwanie, red. B. Rydliński, S. Sowiński, R. Zenderowski, Wydawnictwo Naukowe UKSW, Warszawa 2018, s. 373-381.

41 U. Nothelle-Wildfeuer, Die Sozialprinzipien der Katholischen Soziallehre, w: Handbuch der Katholischen Soziallehre, red. A. Rauscher i in., Duncker \& Humblot, Berlin 2008, s. 146.

42 M. Wódka, Między moralnościa kamieni a prawami człowieka, Wydawnictwo KUL, Lublin 2015, s. 80 . 
dotychczasowej realizacji przez państwo. Nie oznacza to jednak negowania istnienia dobra wspólnego ludzkości ${ }^{43}$.

Funkcjonowanie państwa zależy przede wszystkim od czynnika koordynującego, tzn. od władzy wyposażonej w odpowiednie uprawnienia. Władza w państwie reprezentuje całe społeczeństwo i służy dobru wspólnemu tego społeczeństwa poprzez ukierunkowanie działalności jednostek ludzkich oraz różnych mniejszych lub większych społeczności na dobro wspólne całości. W ten sposób władza zabezpiecza tworzenie ładu społecznego w państwie. Podobnie jak samo państwo, tak i władza w państwie ma swe źródło w społecznej naturze ludzkiej, a ostatecznie w Bogu, który stworzył człowieka do życia w społeczności.

Dobro wspólne zatem stanowi legitymizację, rację i sens istnienia państwa. Wymaga ono służebnie rozumianej aktywności państwa w zakresie tworzenia prawa, sprawowania władzy i zapewnienia dobrobytu. Współczesnemu państwu stawia się trzy podstawowe zadania: 1) ustanowienie porządku prawnego respektującego koncepcję człowieka jako osoby i dobra wspólnego, 2) zagwarantowanie pokoju wewnętrznego i zewnętrznego, co wiąże się z dysponowaniem władzą w zakresie sił porządkowych (policja) i militarnych, 3) dążenie do dobrobytu wszystkich obywateli. W KNS podkreśla się, że władza w dążeniu do dobra wspólnego ma być ,jedynie" przewodnikiem i organizatorem, a nie jego realizatorem. Państwo ma tylko stwarzać warunki do inicjatywy osób indywidualnych i zorganizowanych w różnych społecznościach, dawać bodziec do rozwoju. W razie potrzeby pomagać, zastępczo uzupełniać inne podmioty, ale nie wyręczać ich w samodzielnym działaniu.

Odpowiednio do każdej z tych kategorii zadań państwo na mocy swych uprawnień „od góry” domaga się wkładu „od dołu” - od zobowiązanych obywateli lub instytucji gospodarczych, zazwyczaj w formie danin finansowych albo też świadczeń osobistych, jak np. służba wojskowa. Należy przy tym podkreślić, że dobro wspólne stanowi dla władzy politycznej jednocześnie jej legitymizację oraz granice jej działania. Mimo wspomnianego braku instytucji, mogącej w tym względzie w pełni zastąpić państwo, coraz częściej dzieli ono odpowiedzialność za realizację dobra wspólnego swoich obywateli, z jednej strony z instytucjami globalnymi i regionalnymi, a z drugiej ze społeczeństwem obywatelskim zorganizowanym w pozarządowe stowarzyszenia.

\section{Zakończenie}

Zarysowana personalistyczna koncepcja dobra wspólnego i zasady etyczno-społecznej wspierającej jego realizację ma charakter dynamiczny. Inspiracją

${ }^{43}$ J. Szymczyk, Wokół podstawowych zasad..., s. 48. 
do ich rozwoju są szybkie przemiany rzeczywistości społecznej w obszarze społecznym, gospodarczym, politycznym i kulturowym. Dążenie do zapewnienia możliwości integralnego doskonalenia się osoby ludzkiej wymaga poszukiwania optymalnych rozwiązań, chociażby zmian w kontekście cyfryzacji i globalizacji ${ }^{44}$. W KNS etycznym wyznacznikiem i miarą oceny nowych propozycji organizacji szeroko rozumianego życia społecznego pozostaje koncepcja człowieka jako osoby i stojące na jej straży podstawowe zasady etyczno-społeczne. J. Szymczyk dostrzega w ideach rozwijanych w LSKNS $\mathrm{w}$ tym względzie spory potencjał.

\section{Bibliografia}

Chwaszcz J., Niewiadomska I., Fel S., Wiechetek M., Palacz-Chrisidis A., Innowacyjne narzędzia do diagnozy potencjału readaptacyjnego osób zagrożonych wykluczeniem społecznym i zawodowym, Wydawnictwo Naukowe PWN, Warszawa 2015.

Fel S., Znaczenie społecznych badań empirycznych dla etyki. Na przykładzie sprawiedliwości społecznej, w: Wolność. Wieczne wyzwanie, red. B. Rydliński, S. Sowiński, R. Zenderowski, Wydawnictwo Naukowe UKSW, Warszawa 2018, s. 373-381.

Fel S., Marczak Ł., Powstanie i status zasady zrównoważonego rozwoju „,Roczniki Nauk Społecznych” 2016, nr 2, s. 185-205, DOI: 10.18290/rns.2016.8(44).2-9.

Franciszek, Encyklika Laudato si', 2015.

Gierycz M., Mała pochwała katolicyzmu. Kościół i polityka w późnej nowoczesności, Wydawnictwo Teologia Polityczna, Warszawa 2021.

Globales Gemeinwohl. Sozialwissenschaftliche und sozialethische Analysen, red. M. Heimbach-Steins i in., Brill - Ferdinand Schöningh, Paderborn 2020.

Jähnichen T., Wiemeyer J., Wirtschaftsethik 4.0. Der digitale Wandel als Wirtschaftsethische Herausforderung, Kohlhammer, Stuttgart 2020.

Kondziela J., Filozofia społeczna, Zagadnienia wybrane, Redakcja Wydawnictw KUL, Lublin 1972.

Kongregacja ds. Wychowania Katolickiego, Wskazania dotyczqce studiów i nauczania doktryny społecznej Kościoła w ramach formacji kapłańskiej, "L'Osservatore Romano” 1989, nr 10, s. 11.

Krucina J., Dobro wspólne. Teoria i jej zastosowanie, TUM Wydawnictwo Wrocławskiej Księgarni Archidiecezjalnej, Wrocław 1972.

Kupny J., Podstawowe zasady życia społecznego, w: Katolicka nauka społeczna. Podstawowe zagadnienia z życia społecznego i politycznego, red. S. Fel, J. Kupny, Księgarnia św. Jacka, Katowice 2007, s. 76-87.

Majka J., Filozofia społeczna, Ośrodek Dokumentacji i Studiów Społecznych, Wrocław 1982.

Marczak Ł., Zasada zrównoważonego rozwoju. Perspektywa społeczno-etyczna, Wydawnictwo Naukowe Uniwersytetu Papieskiego Jana Pawła II w Krakowie, Kraków 2021.

Mazurek F.J., Skwierczyński Z., Lubelska Szkoła Katolickiej Nauki Społecznej, w: Encyklopedia katolicka, t. 11, red. S. Wilk i in., TN KUL, Lublin 2006, kol. 34-36.

Möhring-Hesse M., Wem ist wohl beim Gemeinwohl? Pragmatische Erkundungen eines politischen Konzepts, w: Globales Gemeinwohl. Sozialwissenschaftliche und sozialethische Analysen, red. M. Heimbach-Steins i in., Brill - Ferdinand Schöningh, Paderborn 2020, s. 139-162.

${ }^{44}$ T. Jähnichen, J. Wiemeyer, Wirtschaftsethik 4.0. Der digitale Wandel als Wirtschaftsethische Herausforderung, Kohlhammer, Stuttgart 2020. 
Nell-Breuning O. von, Gemeingut, Gemeinwohl, w: Wörterbuch der Politik, t. 1. Zur christlichen Gesellschaftslehre, red. O. von Nell-Breuning, H. Sacher, Herder, Freiburg im Breisgau 1954, s. 51-58.

Nell-Breuning O. von, Gerechtigkeit und Freiheit. Grundzüge katholischer Soziallehre, Europaverlag, Wien-Zürich-München 1980.

Nothelle-Wildfeuer U., Die Sozialprinzipien der Katholischen Soziallehre, w: Handbuch der Katholischen Soziallehre, red. A. Rauscher i in., Duncker \& Humblot, Berlin 2008, s. 143-163.

Piwowarski W., ABC katolickiej nauki społecznej, Wydawnictwo Diecezjalne, Pelplin 1993.

Popielski K., Wprowadzenie. Wartości i ich społeczno-kulturowe znaczenie, w: Wartości dla życia, red. K. Popielski, Wydawnictwo KUL, Lublin 2008, s. 5-15.

Remele K., Wessen Wohl? Welche Gemeinschaft? Für eine postanthropozentrische Ausweitung des Gemeinwohlverständnisses, w: Globales Gemeinwohl. Sozialwissenschaftliche und sozialethische Analysen, red. M. Heimbach-Steins i in., Brill - Ferdinand Schöningh, Paderborn 2020, s. 163-174.

Schulze R.-O., Gemeinwohl, w: Lexikon der Politik, t. 1. Politische Theorien, red. D. Nohlen, C.H. Beck, München 1995, s. 137-144.

Sobór Watykański II, Konstytucja duszpasterska o Kościele w świecie współczesnym Gaudium et spes, 1965.

Strzeszewski C., Hierarchia dóbr wspólnych a naturalna hierarchia społeczności, „Roczniki Filozoficzne" 1966, t. 14, z. 2, s. 5-11.

Strzeszewski C., Katolicka nauka społeczna, Redakcja Wydawnictw KUL, Lublin 1994.

Szymczyk J., Jakie państwo: opiekuńcze czy pomocnicze?, „Chrześcijanin w Świecie” 1993, R. 23, nr 2 (193), s. 209-231.

Szymczyk J., Odkrywanie wartości. Z problematyki socjologiczno-aksjologicznej, Polihymnia, Lublin 2004.

Szymczyk J., Wokół podstawowych zasad etyczno-społecznych, w: J. Szymczyk, Odkrywanie wartości. Z problematyki socjologiczno-aksjologicznej, Polihymnia, Lublin 2004, s. 11-97.

Szymczyk J., Zasada dobra wspólnego a urzq̨dzanie życia społeczno-gospodarczego, w: Godność osoby ludzkiej w społeczeństwie i gospodarce, red. S. Fel, M. Wódka, Wydawnictwo KUL, Lublin 2014, s. 405-420.

Szymczyk J., Zasada dobra wspólnego w ujęciu przedstawicieli Szkoły Lubelskiej, Lublin 1996 [mps w Archiwum KUL].

Utz A.F., Ethik des Gemeinwohls. Gesammelte Aufsätze 1983-1997, Ferdinand Schöningh, Paderborn 1998.

Vogt M., Globales Gemeinwohl und Nachhaltigkeit, w: Globales Gemeinwohl. Sozialwissenschaftliche und sozialethische Analysen, red. M. Heimbach-Steins i in., Brill - Ferdinand Schöningh, Paderborn 2020, s. 185-207.

Wódka M., Między moralnością kamieni a prawami człowieka, Wydawnictwo KUL, Lublin 2015.

Wulsdorf H., Nachhaltigkeit. Ein christlicher Grundauftrag in einer globalisierten Welt, Friedrich Pustet, Regensburg 2005.

\section{Streszczenie}

Dobro wspólne jest powszechnie postrzegane jako wartość podstawowa. Nie oznacza to jednak jednolitego sposobu jego rozumienia. Celem artykułu jest rekonstrukcja ujęcia dobra wspólnego i zasady dobra wspólnego z perspektywy katolickiej nauki społecznej, a dokładniej podejścia autorów skupionych w Lubelskiej Szkole Katolickiej Nauki Społecznej. Uwzględnia się przy tym szczególnie dorobek Jana Szymczyka, który podjął próbę syntezy wyników badań tego środowiska w obszarze dobra wspólnego. Ujęcie to wpisuje się w zakorzeniony w tradycji arystotelesowsko-tomistycznej personalistyczny nurt filozofii społecznej i oficjalne nauczanie społeczne Kościoła katolickiego. 
Charakteryzuje się łączeniem koncepcji ontycznej i instrumentalnej dobra wspólnego, przyjęciem systemu korelujących ze sobą podstawowych zasad etyczno-społecznych (dobra wspólnego, pomocniczości i solidarności) oraz ideą władzy, dla której dobro wspólne stanowi legitymizację oraz wyznacza granice działania.

Słowa kluczowe: dobro wspólne, zasada dobra wspólnego, katolicka nauka społeczna, Jan Szymczyk

\title{
Common Good as a Value and a Socio-Ethical Principle. The Perspective of Catholic Social Thought
}

\begin{abstract}
Summary
Common good is generally viewed as a fundamental value. This does not mean, however, that all people perceive it in the same, unequivocal manner. The aim of this article is to reconstruct the way of how both common good itself and the principle of common good have been laid out in Catholic Social Thought, and more precisely, how they were portrayed by authors associated with the Lublin School of Catholic Social Thought. The article takes into consideration in particular the works of the late Jan Szymczyk, who attempted to provide a synthesis of the research oeuvre of that scholarly group, with specific reference to the concept of common good. This kind of approach became an inherent part of personalistic trends in social philosophy as well as in the official social teaching of the Catholic Church. It is distinguished by combining the ontic conception of common good with the instrumental one, by adopting the system of correlative, basic socio-ethical principles (common good, subsidiarity, solidarity), and by the notion of power, which is legitimised by common good, and whose limits of action are determined by this very concept.
\end{abstract}

Key words: common good, principle of common good, Catholic Social Thought, Jan Szymczyk 